\title{
Factor X Measurement
}

National Cancer Institute

\section{Source}

National Cancer Institute. Factor X Measurement. NCI Thesaurus. Code C98727.

The determination of the amount of factor $\mathrm{X}$ present in a sample. 